\title{
HUBUNGAN KECEPATAN TERHADAP KETERAMPILAN DRIBBLING PADA PERMAINAN FUTSAL DI AKADEMI DEHASEN KOTA BENGKULU
}

\author{
Meki Saputra $^{1, a)}$, Feby Elra Perdima ${ }^{1)}$ \\ ${ }^{1)}$ Program studi Pendidikan Jasmani Universitas Dehasen Bengkulu \\ ${ }^{a)}$ Corresponding Author: mekisaputra@gmail.com
}

\begin{abstract}
Based on the observations of the activities at Dehasen Academy, that the athletic abilities of the athletes were not good enough that can cause the ball out of control. This problem is thought to be caused by several factors including the low speed of the athlete. This study aims to find out the correlation of the athlete's speed towards Dribbling skills. The method of this study is the correlation method. The population of this study was 25 man players from Dehasen Academy Futsal club, while the samples were taken through total sampling. The place for conducting research at the Unived futsal field collected during April 2019. Speed data was taken with a 40 meter sprint test, and Dribbling skills data taken by the Dribbling test. The data analysis in this study used techniques with correlation analysis. The results of data analysis show that there is a significant correlation between speed $(X)$ on dribbling skills in futsal athletes at Dehasen Academy of Bengkulu City, with a value of rxy $=0.95>r(0.05)(25)=0.396$
\end{abstract}

Keywords: Speed, Dribbling Skills

\section{Abstrak}

Berdasarkan pengamatan peneliti terhadap pelaksanaan Kegiatan di klub Akademi Dehasen, bahwa kemampuan Dribbling para atlet kurang baik sehingga menyebabkan bola sering lepas kendali. Masalah inilah diduga disebabkan oleh beberapa faktor, antara lain rendahnya tingkat kecepatan dari atlet. Penelitian ini bertujuan untuk mengetahui Hubungan Kecepatan terhadap Keterampilan Dribbling.Metode penelitian ini adalah metode korelasional. Populasi penelitian ini seluruh pemain klub Futsal Akademi Dehasen sebanyak 25 orang putera sedangkan sampel diambil secara total sampling, Tempat pelaksanaan penelitian di lapangan futsal Unived, adapun waktu penelitian adalah bulan April 2019. Data kecepatan diambil dengan tes lari sprint 40 meter, dan data Kemampuan Dribbling diambil dengan tes Dribbling. Teknik analisis data penelitian ini menggunakan teknik dengan analisis korelasi. Hasil analisis data menunjukkan bahwa: Terdapat hubungan yang signifikan antara kecepatan $(X)$ terhadap keterampilan dribbling pada atlet futsal di Akdemi Universitas Dehasen Bengkulu, dengan nilai $r x y=0,95>r(0,05)(25)=0,396$

Kata kunci : Kecepatan, Keterampilan Dribbling

\section{Pendahuluan}

Olahraga merupakan wadah untuk seseorang untuk mengembangkan bakat yang ada pada dirinya. Perkembangan olahraga di dunia mempunyai kedudukan yang sangat penting dalam dunia pendidikan. Olahraga dan kesehatan merupakan kebutuhan bagi setiap orang, karena semua orang pasti ingin sehat, tidak seorangpun yang ingin sakit atau terganggu kesehatannya. Kesehatan merupakan salah satu faktor utama yang dapat mempengaruhi kebugaran dan penampilan tubuh, serta harta yang paling berharga yang tidak pernah bisa ditukar dengan apapun. Oleh karena itu setiap orang tentu mendambakan hidup sehat bahagia dan ingin selalu tampak sehat, bugar, penampilan yang menarik dan awet muda, tidak lekas keriput karena menua.

Olahraga merupakan sarana, bukan hanya di Indonesia di negara-negara lainpun setiap orang meluangkan waktu untuk melakukan melakukan aktivitas jasmani, ini terbukti bahwa olahraga 
juga sudah menjadi gaya hidup untuk menuju kehidupan yang sehat. Pelaksanaan pendidikan jasmani dan olahraga merupakan investasi jangka panjang dalam upaya peningkatan kehidupan manusia. Selain itu olahraga juga menjadi sebuah gaya hidup bagi sebagian orang, bahkan untuk sebagian orang yang lain olahraga menjadi sebuah kebutuhan mendasar dalam hidup.

Olahraga juga mempunyai peranan yang sangat penting untuk membantu tercapainya kebugaran jasmani. Pendidikan jasmani dan olahraga pada hakikatnya adalah proses pendidikan yang memanfaatkan aktifitas fisik. Aspek fisik dapat dari kegiatan keolahragaan di masyarakat sebagai upaya menjaga tubuh yang sehat. Pendidikan jasmani dan olahraga merupakan bagian yang tak terpisahkan dari pendidikan umum

Olahraga menjadi sangat penting karena tidak terlepas dari kebutuhan mendasar manusia itu sendiri yang pada prinsipnya selalu bergerak. Olahraga itu sendiri merupakan serangkaian gerak raga yang teratur dan terencana untuk memelihara dan meningkatkan kemampuan gerak yang bertujuan untuk mempertahankan hidup serta meningkatkan kualitas hidup seseorang. Tujuan seseorang berolahraga adalah untuk meningkatkan kesehatan yang menyeluruh baik jasmani maupun rohani.

Olahraga yang mengarah ke prestasi menjadi suatu alasan seseorang menyukai olahraga. Sejalan dengan perkembangan dan peningkatan fisik yang beranjak matang maka perkembangan motorik sudah dapat terkoordinasi dengan baik dari tingkat anak-anak, remaja bahkan ke tingkat dewasa. Usia anak didik ditingkat sekolah dasar merupakan masa yang ideal untuk belajar keterampilan yang berkaitan dengan motorik ini, seperti halnya dengan bermain futsal.

Olahraga futsal merupakan salah satu cabang olahraga yang termasuk dalam permainan bola besar. Olahraga futsal ini dimainkan oleh lima orang termasuk penjaga gawang dan biasanya dimainkan di dalam suatu ruangan. Futsal menjadi salah satu permainan alternatif sepakbola. Seperti halnya dengan olahraga sepakbola, futsal juga olahraga yang memiliki minat yang banyak oleh kalangan masyarakat, dikarenakan olahraga ini dapat dimainkan disemua lapisan masyarakat baik kalangan atas maupun kalangan bawah. Futsal merupakan cabang olahraga yang popular dan digemari oleh seluruh lapisan masyarakat yang sudah dianggap sebagai gaya hidup yang mampu menciptakan sebuah permainan yang berbalut dengan kompetisi dan persaingan. Dengan tuntutan prestasi dan perkembangan futsal yang semakin pesat dan dengan adanya kompetisi yang sering diadakan tersebut, maka klub-klub berlombalomba untuk menaikkan level permainan mereka baik dari segi pemain, teknik, taktik maupun strategi.

Berdasarkan penjelasan yang telah diuraikan di atas dalam kaitannya permainan futsal yang ada di Dehasen dan tuntutan prestasi dari tingkat mahasiswa baik di daerah kota bengkulu maupun di tingkat nasional, maka perlu adanya peningkatan kembali mengenai kenaikkan level permainan dan gerakan kecepatan terhadap keterampilan dribbling. Hal ini berkaitan dengan perpaduan kecepatan dalam melakukan dribbling yang masih kurang baik dalam pengontrolan bola serta tetap menjaga kondisi fisik secara baik.

Kondisi fisik sangat erat kaitannya dengan kecepatan. Kecepatan merupakan kemampuan untuk berjalan, berlari, dan bergerak dengan sangat cepat. Kondisik fisik yang menjadi salah satu permasalahan mengapa futsal di akademi dehasen belum dirasakan prestasi yang membanggakan. Dalam hal kaitannya mengenai perkembangan kecepatan berarti juga meliputi pengembangan skill. Hal ini berkaitan dengan gerakan pengembangan skill dalam dribbling, dikarenakan pada saat melakukan dribbling masih terlalu mudah kehilangan bola dikarenakan kecepatan dalam melakukan dribbling. Selain mental yang perlu adanya peningkatan, keterampilan dasar harus dimiliki oleh setiap pemain, baik keterampilan dribbling, shooting, passing, controlling untuk mencapai suatu kemenangan.

Berdasarkan pembahasan mengenai teknik dasar yang ada di atas mengenai teknik dasar, dribbling merupakan salah satu teknik dasar yang harus dikuasi oleh setiap pemain futsal. Dribbling merupakan salah satu teknik yang selalu digunakan pemain untuk mengecoh lawan sehingga membongkar pertahanan lawan. Selain keterampilan dribbling, kecepatan dalam futsal dapat disebutkan sebagai motor dalam setiap aktivitas gerak yang dilakukan guna untuk mendapatkan hasil yang ingin dicapai dan proses pencapaian prestasi semaksimal mungkin khususnya dalam permainan futsal di Akademi Dehasen.

Kualitas dribbling yang baik sangat membutuhkan latihan fisik yang terprogram dalam kecepatan dan dengan bimbingan pelatih untuk mengarahkan bagiamana dapat menghasilkan kecepatan untuk dapat melakukan 
dribbling yang terarah dengan teknik yang benar. Hasil dari pengamatan yang peneliti lakukan di Akademi Dehasen Kota Bengkulu, dan beberapa permasalahan yang muncul maka peneliti mengajukan sebuah judul untuk melakukan proses penelitian yaitu "Hubungan Kecepatan Terhadap Keterampilan Dribbling Pada Permainan Futsal di Akademi Dehasen.

Futsal merupakan satu diantara sekian banyak permainan yang digemari oleh penduduk di seluruh belahan dunia. Menurut Asriadi (2014:1) "futsal merupakan jenis permainan yang dimainkan dengan segala aspek yang lebih sederhana dibandingkan sepakbola". Futsal juga merupakan suatu aktifitas olahraga atau permainan yang dimainkan di dalam ataupun di luar ruangan. Olahraga futsal ini juga memiliki keunggulan, yaitu lapangan tidak luas, dimainkan oleh lima pemain termasuk kiper dan memakai bola ringan, serta memiliki minat yang banyak oleh kalangan masyarakat, dikarenakan olahraga ini dapat dimainkan dari semua lapisan masyarakat baik pelajar ataupun mahasiswa, dari kalangan atas maupun kalangan bawah, baik anak kecil sampai tingkat yang lebih dewasa.

Dalam permainan futsal, penggunaan kaki bagian dalam dan luar sering dipakai untuk melakukan dribbling. Menurut Mulyono(2014: 54) "dribbling atau menggiring bola sama seperti sepak bola yaitu untuk menguasai bola dan menciptakan peluang mencetak gol". Teknik ini harus dikuasi oleh setiap pemain futsal agar mempu menguasai bola dengan baik saat bola berada di kakinya. Pemain futsal yang memiliki kemampuan menggiring bola yang baik akan berusaha melewati lawan apabila bola tidak dapat di passing ke teman karena ketatnya pertahanan.

Kecepatan merupakan kualitas kondisional yang memungkinkan seseorang untuk bereaksi secara cepat bila dirangsang dan untuk menampilkan atau melakukan gerakan secepat mungkin. Kecepatan termasuk salah satu komponen kondisi fisik yang banyak berpengaruh terhadap penampilan atlit. Kecepatan juga merupakan potensi tubuh yang merupakan modal dalam banyak hal yang berhubungan dengan gerak. Menurut Widiastuti, (2017:125) "Kecepatan adalah kemampuan untuk melakukan gerakan-gerakan yang sejenis secara berturut-turut dalam waktu yang singkat, atau kemampuan untuk menempuh suatu jarak dalam waktu yang sesingkat-singkatnya". Terdapat dua jenis kecepatan yang sangat dibutuhkan dalam olahraga, yaitu kecepatan reaksi dan kecepatan bergerak

\section{Metode Penelitian}

Metode penelitian penelitian menurut Subagyo (2015:2) merupakan suatu cara atau jalan untuk memperoleh kembali pemecahan terhadap segala permasalahan. Variabel bebas disini adalah kecepatan sebagai variabel (X), sedangkan variabel terikatnya adalah keterampilan dribbling sebagai (Y). Metode penelitian yang digunakan dalam penelitian ini adalah dengan menggunakan metode korelasional (correlational research)

Sugiyono, (2009:115) menjelaskan "Populasi adalah wilayah generalisasi yang terdiri atas obyek atau subyek yang mempengaruhi kuantitas dan karakteristik tertentu yang ditetapkan oleh peneliti untuk dipelajari dan kemudian ditarik kesimpulannya". Populasi dalam penelitian ini yaitu seluruh pemain futsal di Akademi Dehasen yang berjumlah 25 orang.

Menurut Sugiyono (2009:116) sampel adalah sebagian dari jumlah dan karakteristik yang dimiliki populasi tersebut. Sampel yang digunakan dalam penelitian ini adalah dengan menggunakan total sampling. Dimana seluruh populasi dijadikan sampel yaitu berjumlah 25 orang.

\section{Hasil Penelitian}

Sesuai dengan rancangan penelitian dan studi kepustakaan yang telah dikemukan terdahulu, analisis data dilakukan terhadap hasil tes kedua variabel. Kedua variabel tersebut adalah Kecepatan Lari 40 Meter sebagai variabel bebas dan keterampilan dribbling pada atlet futsal Akademi Dehasen sebagai variabel terikatnya. Selanjutnya akan dijabarkan hasil dari penelitian sebagai berikut:

Hasil Tes Kecepatan (X)

Dari hasil pengukuran Kecepatan yang dilakukan terhadap atlet bolavoli Universitas Dehasen Bengkulu didapat skor tertinggi 05.63 dan skor terendah 07.50, berdasarkan data tersebut rata-rata hitung (mean) 6.32 dan simpangan baku (standar deviasi) 0.5. Distribusi kategori kecepatan yang dilakukan terhadap atlet bolavoli Universitas Dehasen Bengkulu dapat dilihat pada tabel berikut : 


\begin{tabular}{l}
\hline \multicolumn{4}{|c|}{ Tabel 1. Distribusi Frekuensi Data } \\
\begin{tabular}{|c|c|c|c|}
\hline No & $\begin{array}{l}\text { Kelas } \\
\text { Interval }\end{array}$ & $\begin{array}{l}\text { Frekuensi } \\
\text { Absolut }\end{array}$ & $\begin{array}{l}\text { Frekuensi } \\
\text { Relatif } \\
(\%)\end{array}$ \\
\hline 1. & $\begin{array}{c}05.63- \\
06.00\end{array}$ & 8 & $32 \%$ \\
\hline 2. & $\begin{array}{c}06.01- \\
06.38\end{array}$ & 7 & $28 \%$ \\
\hline 3. & $\begin{array}{c}06.39- \\
06.76\end{array}$ & 6 & $24 \%$ \\
\hline 4. & $\begin{array}{c}06.77- \\
07.14\end{array}$ & 1 & $4 \%$ \\
\hline 5. & $\begin{array}{c}07.15- \\
07.52\end{array}$ & 3 & $12 \%$ \\
\hline
\end{tabular}
\end{tabular}

Dari tabel di atas dapat disimpulkan bahwa dari 25 atlet Futsal Universitas Dehasen Bengkulu sebanyak 8 orang atlet (32\%) memiliki kategori nilai 05.63-06.00. 7 orang atlet (28\%) memiliki kategori nilai 06.01-06.38, 6 orang atlet (24\%) memiliki kategori nilai 06.39$06.76,1$ orang atlet $(4 \%)$ memiliki kategori nilai $06.77-07.14,3$ orang atlet $(12 \%)$ memiliki kategori nilai 07.15-07.52,

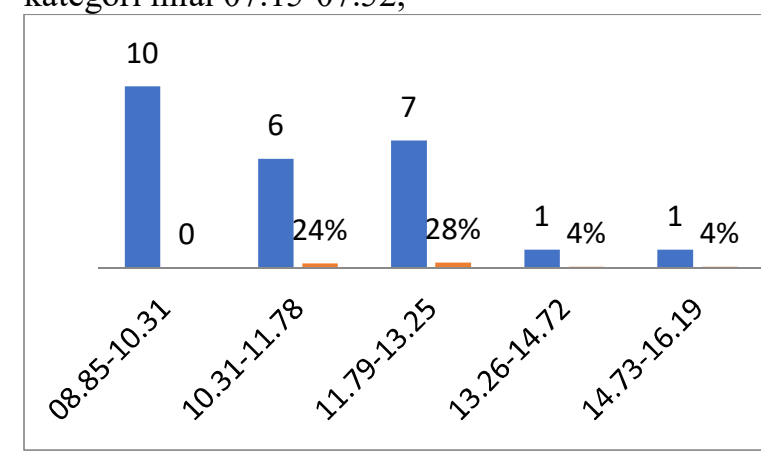

Dari hasil pengukuran dribbling yang dilakukan terhadap atlet Futsal Akademi Universitas Dehasen Bengkulu terdapat skor tertinggi 8.85 dan skor terendah 16.16, berdasarkan data tersebut rata-rata hitung (mean) 11.05 dan simpangan baku (standar deviasi) 1.67. Distribusi kategori keterampilan dribbling yang dilakukan atlet Akademi Dehasen Bengkulu dapat dilihat pada tabel berikut :

Tabel 4.2 Distribusi Frekuensi Hasil Tes

Keterampilan dribbling (Y).

\begin{tabular}{|c|c|c|c|}
\hline No & Kelas Interval & Frekuensi Absolut & $\begin{array}{l}\text { Frekuensi Relatif } \\
\text { (\%) }\end{array}$ \\
\hline 1. & $08.85-10.31$ & 10 & $40 \&$ \\
\hline 2. & $10.31-11.78$ & 6 & $24 \%$ \\
\hline 3. & $11.79-13.25$ & 7 & $28 \%$ \\
\hline 4. & $13.26-14.72$ & 1 & $4 \%$ \\
\hline 5. & $14.73-16.19$ & 1 & $4 \%$ \\
\hline
\end{tabular}

Dari tabel di atas dapat disimpulkan bahwa dari 25 atlet futsal sebanyak 10 orang atlet (40\%) memiliki kategori nilai $08.85-10.31,6$ orang atlet (24\%) memiliki kategori nilai 10.31-11.78, 7 orang atlet (28\%) memiliki kategori nilai 11.79 $13.25,1$ orang atlet $(4 \%)$ memiliki kategori nilai 13.26-14.72, 1 orang atlet (4\%) memiliki kategori nilai 14.73-16.19..

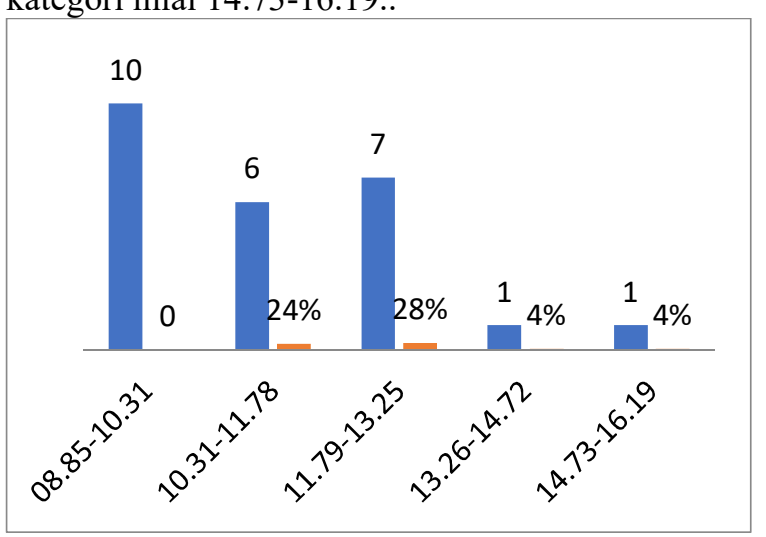

Sebelum melakukan pengujian hipotesis yang diajukan dalam penelitian ini, maka terlebih dahulu dilakukan uji prasyarat analisis data yaitu uji normalitas data. Dalam uji normalitas data ini peneliti menggunakan uji normalitas data lilliefors. Adapun hasil analisis dapat dilihat pada tabel di bawah ini :

Tabel 4.3 Uji Normalitas Data

$$
\text { Variabel X dan Y }
$$

\begin{tabular}{|c|l|c|c|c|}
\hline No & \multicolumn{1}{|c|}{ Variabel } & $\mathbf{L}$ hitung & $\mathbf{L}$ tabel & Keterangan \\
\hline 1. & Kecepatan & $\mathbf{0 . 1 2 8}$ & $\mathbf{0 , 1 7 3}$ & Normal \\
\hline 2. & Keterampilan Dribbling & $\mathbf{0 . 1 3 0}$ & $\mathbf{0 , 1 7 3}$ & Normal \\
\hline
\end{tabular}

Dari tabel di atas menunjukan bahwa hasil pengujian untuk kecepatan lari $(\mathrm{X})$ skor $\mathrm{L}_{\text {hitung }}$ 0,128 dengan $n=25$ sedangkan $\mathrm{L}_{\text {tabel }}$ pada taraf signifikan 5\% atau 0,05 diperoleh 0,173. Karena $\mathrm{L}_{\text {hitung }}$ lebih kecil dari $\mathrm{L}_{\text {tabel }}$ sehingga dapat 
disimpulkan bahwa skor yang diperoleh dari kecepatan berdistribusi normal. Selain itu tabel tersebut di atas juga menunjukan bahwa hasil pengujian untuk keterampilan dribbling (Y) skor $\mathrm{L}_{\text {hitung }}=0,130$ dengan $\mathrm{n}=25$, sedangkan $\mathrm{L}_{\text {tabel }}$ pada taraf signifikan $5 \%$ atau 0,05 diperoleh 0,173 . Karena $L_{\text {hitung }}$ lebih kecil dari pada $L_{\text {tabel }}$ sehingga dapat disimpulkan bahwa skor yang diperoleh dari keterampilan dribbling berdistribusi normal.

Uji prasyarat analisis data setelah melakukan uji normalitas data maka dilakuakan uji homogenitas data dengan menggunakan uji varians (uji $\mathrm{F}$ dari Hevley) dapat di lihat pada tabel berikut ini :

Tabel. 4.4 Uji Homogenitas Data Variabel X dan Y

\begin{tabular}{|c|l|l|c|c|c}
\hline No & \multicolumn{1}{|c|}{ Variabel } & Varians & F hitung & F tabel & Ket \\
\hline 1 & Kecepatan & 0.5 & \multirow{2}{*}{3.31} & \multirow{2}{*}{3,40} & Homogen \\
\hline 2 & Keterampilan Dribbling & 1.65 & & \\
\hline
\end{tabular}

Dari tabel di atas menunjukan bahwa hasil pengujian varians untuk Kecepatan (X) didapat skor 0.5 , sedangkan hasil pengujian varians untuk keterampilan dribbling (Y) didapat skor 1.65 sehinggga didapat $\mathrm{F}_{\text {hitung }}$ dengan menggunakan uji $\mathrm{F}$ dari Hevley diperoleh skor $3, .31$. Sedangkan untuk nilai $\mathrm{F}_{\text {tabel }}$ dengan tarap signifikan $5 \%$ atau 0,05 adalah $=3,40$ karena $F_{\text {hitung }}$ (3.31) lebih kecil dari $F_{\text {tabel }}(3,40)$ maka data dapat disimpulkan bahwa skor yang diperoleh untuk kecepatan (X) terhadap keterampilan dribling (Y) memiliki data yang homogen.

Analisis data penelitian yang digunakan untuk menguji hipotesis terdiri atas analisis korelasi sederhana. Hipotesis dalam penelitian ini adalah "Ada hubungan yang signifikan antara kecepatan terhadap keterampilan dribbling pada atlet Futsal Akademi Dehasen Bengkulu". Hasil uji hipotesis dengan menggunakan analisis koefisien korelasi product moment dapat dilihat pada tabel 4.5 berikut ini :
Tabel 4.5 Koefisien Korelasi Variabel (X) Terhadap Variabel (Y).

\begin{tabular}{|c|c|c|c|}
\hline Korelasi & rhitung & rtabel & Keterangan \\
\hline $\mathrm{r}_{\mathrm{xy}}$ & 0,95 & 0,396 & Signifikan \\
\hline
\end{tabular}

Berdasarkan hasil analisis tersebut di atas diperoleh koefisien korelasi kecepatan terhadap keterampilan dribbling atlet futsal Akademi sebesar 0,95 bernilai positif, artinya semakin besar skor yang diperoleh maka semakin kuat hubungan antara kedua variabel. Uji keberartian koefisien korelasi tersebut dilakukan dengan cara harga $r_{\text {hitung dengan }} r_{\text {tabel }}$ pada $\alpha=5 \%$ dengan $\mathrm{N}=25$ diperoleh $\mathrm{r}_{\text {tabel }}$ sebesar 0,396 Karena koefisien korelasi antara $r_{x . y}=0,95>r_{(0,5)(25)}=$ 0,396 berarti hubungan kecepatan terhadap keterampilan dribbling atlet futsal Akademi Dehasen Bengkulu adalah signifikan. Dengan demikian hipotesis yang berbunyi "ada hubungan yang kuat antara kecepatan terhadap keterampilan dribbling atlet futsal Akademi Dehasen Bengkulu", diterima. Artinya ada hubungan kecepatan terhadap keterampilan dribbling atlet futsal Akademi Dehasen Bengkulu

\section{Pembahasan}

Menurut Mulyono(2014: 54) “dribbling atau menggiring bola sama seperti sepak bola yaitu untuk menguasai bola dan menciptakan peluang mencetak gol". Teknik ini harus dikuasi oleh setiap pemain futsal agar mempu menguasai bola dengan baik saat bola berada di kakinya. Pemain futsal yang memiliki kemampuan menggiring bola yang baik akan berusaha melewati lawan apabila bola tidak dapat di passing ke teman karena ketatnya pertahanan.

Menggiring bola adalah menendang bola terputus-putus atau pelan-pelan". Menggiring bola bertujuan untuk mendekatkan bola ke pertahanan lawan, melewati lawan, dan menghambat permainan. Kaki yang digunakan untuk menggiring bola sama dengan kaki yang digunakan untuk menendang bola. Dribbling merupakan kemampuan yang dimiliki setiap pemain dalam menguasai bola sebelum diberikan kepada temannya untuk menciptakan peluang dalam mencetak gol. Menggiring bola dilakukan dengan menggunakan sisi bawah sepatu, kaki bagian dalam dan dengan menggunakan kaki bagian luar, serta punggung kaki. Untuk mengahasilkan dribbling yang maksimal maka di butuhkan suatu kondisi fisik seperti komponen kecepatan yang mendukung. Ada pun pengertian 
kecepatan adalah Kecepatan adalah kemampuan untuk melakukan gerakan yang sejenis secara berturut-turut dalam waktu yang sesingkatsingkatnya, atau kemampuan untuk menempuh suatu jarak dalam waktu yang sesingkatsingkatnya.

Berdasarkan hasil penelitian menunjukan bahwa ada hubungan yang signifikan antara kecepatan terhadap keterampilan dribbling atlet futsal Akademi Dehasen Bengkulu, dengan nilai $r_{x . y}=0,95>r_{(0,05)(25)}=0,396$. Dari hasil penelitian ini didukung oleh (Novita, 2010: 1) Dribbling merupakan salah satu teknik yang selalu digunakan pemain untuk mengecoh lawan sehingga membongkar pertahanan lawan. Selain keterampilan dribbling, kecepatan dalam futsal dapat disebutkan sebagai motor dalam setiap aktivitas gerak yang dilakukan guna untuk mendapatkan hasil yang ingin dicapai dan proses pencapaian prestasi semaksimal mungkin khususnya dalam permainan futsal di Akademi Dehasen.

Kualitas dribbling yang baik sangat membutuhkan latihan fisik yang terprogram dalam kecepatan dan dengan bimbingan pelatih untuk mengarahkan bagiamana dapat menghasilkan kecepatan untuk dapat melakukan dribbling yang terarah dengan teknik yang benar. Dari penjelasan di atas dapat disimpulkan bahwa salah satu tahapan yang harus dilakukan didalam melakukan dribbling harus memiliki kecepatan yang tinggi. Pernyataan inilah yang menjadikan dasar bahwa kecepatan sangat dibutuhkan dalam melakukan dribbling dalam permainan futsal. Dengan kecepatan lari yang besar maka persentase keberhasilan dalam melakukan dribbling akan semakin tinggi

\section{Kesimpulan}

Berdasarkan hasil penelitian dan pembahasan, maka didapat kesimpulan sebagai berikut : Terdapat hubungan yang signifikan antara kecepatan (X) terhadap keterampilan dribbling pada atlet futsal di Akdemi Universitas Dehasen Bengkulu, dengan nilai $r_{x y}=0,95>$ $r_{(0,05)(25)}=0,396$

\section{Daftar Pustaka}

Arikunto, Suharsimi. 2006. Prosedur Penelitian. Jakarta: Asdi Mahasatya.

Falensia Kurnia Juli Pratiwi. 2016. Hubungan Minat Dan Motivasi Dengan Keterampilan Futsal
Remaja Putri Di Bandar Lampung (Skipsi Publis).

FIFA. 2015. Futsal Laws Of The Game. Lhaksana, Justinus. 2012. Taktikdan Strategi Futsal Modern. Jakarta: Be Champion.

Lhaksana, Justinus dan Ishak H. Pordasi. 2017. Inspirasi dan Spirit Futsal. Jakarta: Raih Asa Sukses.

Lubis, Johansyah. 2013. Panduan Praktis Penyusun Program Latihan. Jakarta: PT RajaGrafindo Persada.

Mulyono, Muhammad Asriady. 2017. Buku Pintar Panduan Futsal. Jakarta Timur: Anugrah.

Subagyo, P. Joko. 2015. Metode Penelitian Dalam Teori Dan Praktek. Jakarta: Rineka Cipta.

Sugiyono. 2009. Metode Penelitian Kualitatif dan Kuantitatif $R \& D$. bandung. Alfabeta.

Sutanto, Teguh. 2016. Buku Pintar Olahraga. Yogyakarta: Pustaka Baru Press.

Tangkudung, James dan Wahyuningtyas Puspitorini. 2012. Kepelatihan Olahraga "Pembinaan Prestasi Olahraga". Jakarta: Cerdas Jaya.

Vinsencius Budi Wicaksono. 2013. Kemampuan Power Otot Tungkai, Kekuatan Otot Tungkai, dan Kelincahan Siswa yang Mengikuti Ekstrakurikuler Sepakbola dan Futsal di SMP Negeri 3 Godean (Skipsi Publis). 